\title{
The Effects of Vitamin D on Metabolic Profiles in Women with Polycystic Ovary Syndrome: A Systematic Review
}

\author{
Authors
}

Ashley Williams ${ }^{1}$, Jeganathan Ramesh Babu1, ${ }^{1}$, Danielle D. Wadsworth ${ }^{3}$, Donna Burnett ${ }^{1}$, Thangiah Geetha ${ }^{1,2}$

\section{ABSTRACT}

This systematic review aims to evaluate all epidemiological evidence in the literature linking the effect of vitamin D supplementation to metabolic and hormonal functions in women with polycystic ovary syndrome. The literature search was performed with two databases, namely Medline/PubMed and Web of Science, until 20 May 2019 for both observational and experimental studies concerning relationships between vitamin $\mathrm{D}$ and polycystic ovary syndrome. A total of ten studies with randomized, double-blinded, and placebo-controlled trial design from 2008 to 2019 were selected for this review. The inclusion criteria were women 18-45 years of age with polycystic ovary syndrome and comparing the metabolic or endocrine parameters between placebo and vitamin $\mathrm{D}$ supplementation groups. A total of ten studies were selected for this review. We found that vitamin D supplementation had a significant effect on insulin metabolism, total serum testosterone, hirsutism, C-reactive protein, and total antioxidant capacity in women with polycystic ovary syndrome. Evidence from available randomized controlled trials suggests that patients with polycystic ovary syndrome should take vitamin D supplementation for the beneficial effect of metabolic profiles. However, future research is needed regarding the beneficial effects in women who are non-obese with polycystic ovary syndrome, as well as more studies with larger sample sizes.

\author{
Correspondence \\ Thangiah Geetha PhD \\ Department of Nutrition, Dietetics, and \\ Hospitality Management \\ 101B Poultry Science Building \\ 260 Lem Morrison Drive \\ Auburn University, Auburn \\ Alabama 36849 \\ USA \\ Tel.: + 1334844 7418, Fax: + 13348443268 \\ thangge@auburn.edu
}

\section{Introduction}

Polycystic ovary syndrome (PCOS) is a common endocrine disorder in women of reproductive age (15-44 years), with a prevalence of $5-10 \%$ [1]. PCOS is known as a reproductive disorder that is characterized by polycystic ovaries, menstrual abnormalities, hyperandrogenism, chronic inflammation, infertility, obesity, and increased risk of type 2 diabetes mellitus, metabolic syndrome, and cardiovascular disease. Although several diagnostic criteria have been reported for PCOS, Rotterdam criteria are known to be the most appropriate and important. In May 2003 a consensus workshop was held in Rotterdam indicated the diagnosis of PCOS was made by the presence of at least two of the following features: irregular or failed ovulation, clinical symptoms, and laboratory findings of hyperandrogenism or the presence of polycystic ovarian morphology confirmed by ultrasonography [2]. Another common characteristic in PCOS patients is insulin resistance, which plays a vital role 
in its pathogenesis. Today, $50-80 \%$ of patients with PCOS exhibit insulin resistance syndrome [3]. However, the etiology of insulin resistance in PCOS is not entirely clear, and many studies are examining the efficiency of insulin resistance reduction strategies in PCOS treatment.

Recently, there has been a focus on vitamin $D$ supplementation as an adjunct of PCOS [4]. Many studies have demonstrated that vitamin $\mathrm{D}$ deficiency is common among women with PCOS, with $67-85 \%$ having serum 25 -hydroxyvitamin D [25(OH) D] concentrations of $20<\mathrm{ng} / \mathrm{ml}$ (or $50 \mathrm{nmol} / \mathrm{l}$ ) [5]. Ovulation problems, menstrual irregularities, and infertility are subsequent challenges encountered during the periods of low vitamin D status [2]. Also, vitamin $D$ deficiency is associated with increased insulin resistance and elevated levels of total testosterone and dehydroepiandrosterone sulfate (DHEAS) in patients with PCOS [6,7]. The active form of vitamin $D, 1,25$-dihydroxyvitamin $D_{3}$ is a steroid hormone, which binds to nuclear receptors and regulates the expression of many genes until it reaches its target tissue for initial effect $[8,9]$. The primary role of vitamin $D$ is in bone mineralization and other metabolic processes in the human body, such as calcium and phosphate homeostasis and skeletal growth [10]. Vitamin D receptors (VDRs) are distributed across various human tissues, including ovary and endometrium, suggesting an active role of vitamin $D$ in female reproductive tissues $[6,8]$. Lastly, PCOS is also related to abnormal calcium and phosphate metabolism, and the patients are characterized by elevated levels of phosphorus and parathyroid hormone (PTH) and decreased levels of vitamin D, which may be associated with obesity $[6,11]$.

Low vitamin D status correlates with obesity, which is one of the fastest-growing health concerns worldwide. Studies involving large cohorts have found that obesity is inversely associated with serum 25 -hydroxyvitamin D concentrations [12,13]. Vitamin D deficiency is associated with increased insulin resistance, testosterone, and DHEAS levels, which are important risk factors of PCOS [14]. However, studies on vitamin D supplementation in obese patients with PCOS have yielded mixed results. Some of the studies suggest beneficial effects on glucose metabolism and insulin resistance, especially when vitamin D is given continuously in lower (<4000 IU/day) doses, and improvements in menstrual frequency and hyperandrogenism, whereas others demonstrate no significant improvements $[15,16]$. Therefore, the objective of this systematic review is to quantitatively summarize existing evidence to determine whether vitamin D supplementation will have a positive effect on the metabolic and hormonal functions in women with PCOS.

\section{Materials and Methods}

\section{Search strategy and engines}

Relevant studies were identified from the following databases: Medline/PubMed and Web of Science. Databases were searched using the search strategy from the earliest available date to 20 May 2019. The search strategy included the terms of PCOS, vitamin D supplementation, and vitamin D and polycystic ovary syndrome. We also manually searched reference lists of all eligible articles and previous reviews on relevant topics for additional studies.

\section{Inclusion and exclusion criteria}

All human studies with randomized, double-blinded, placebo-controlled trial design published in the English language from 2008 to 2019 were assessed. Studies were included in the review if they fulfilled the following criteria: (1) reporting data from all women 18-45 years of age with PCOS; (2) presented the comparison of metabolic or endocrine parameters between vitamin D supplementation and placebo groups, high and low doses of vitamin D supplementation, and calcium plus vitamin D supplementation; and (3) enrolled women who were diagnosed with PCOS using Rotterdam European Society of Human Reproduction and Embryology (ESHRE)/ American Society of Reproductive Medicine (ASRM) or National Institute of Health (NIH) criteria.

Studies were excluded from the study if they met the following criteria: (1) studies that enrolled women who were pregnant during the study; (2) studies reporting diseases, such as hyperthyroidism, diabetes or impaired glucose tolerance, or other hormonerelated disorders; (3) articles not published in English and (4) studies that were not specific about the diagnosis of PCOS.

\section{Data extraction}

Ultimately, a total of ten studies met the selection criteria. From each study, the following information was extracted: the first author's name; year of publication; place and year of data collection; study design; type and size of the sample; diagnostic criteria for PCOS; the interventions subjects received (type and frequency); and the primary outcomes. We extracted the results of interest at the longest point of completed follow up which included serum vitamin D levels, total antioxidant capacity (TAC), C-reactive protein (CRP), total testosterone, homeostasis model of assessment- estimated insulin resistance (HOMA-IR), sex-hormone binding globulin (SHBG), dehydroepiandrosterone sulfate (DHEAS), modified Ferriman-Gallwey (mF-G), malondialdehyde (MDA), nitric oxide (NO), and regular menstrual cycles.

To determine the sample size, all studies considered type one error at 0.05 and type two error of 0.20 (power $=80 \%$ ). Also, each used the Kolmogorov-Smirnov test to examine the normal distribution of variables. One-way analysis of variance (ANOVA) was used to detect differences in anthropometric characteristics and dietary intakes between the groups. The $p$-values of $<0.05$ were considered statistically significant.

\section{Results}

A total of ten studies were included in this systematic review as shown in > Fig. 1. Seven studies compared the effect of vitamin D supplementation with placebo [5, 7, 17-21], two studies compared calcium plus vitamin D with placebo [17,22], and one study compared low and high dose of vitamin D with metformin [15]. Vitamin D was given in a daily dose of $4000 \mathrm{IU} /$ day, and metformin tablet at initial dose of $500 \mathrm{mg}$, which was gradually increased during the first 3 weeks to $1500 \mathrm{mg} /$ day to minimize the side effects [15]. Eight studies defined PCOS based on criteria of Rotterdam European Society for Human Reproduction \& Embryology, and two defined PCOS based on NIH criteria. Studies were conducted in Iran, the United States of America, Austria, and the United Kingdom. 


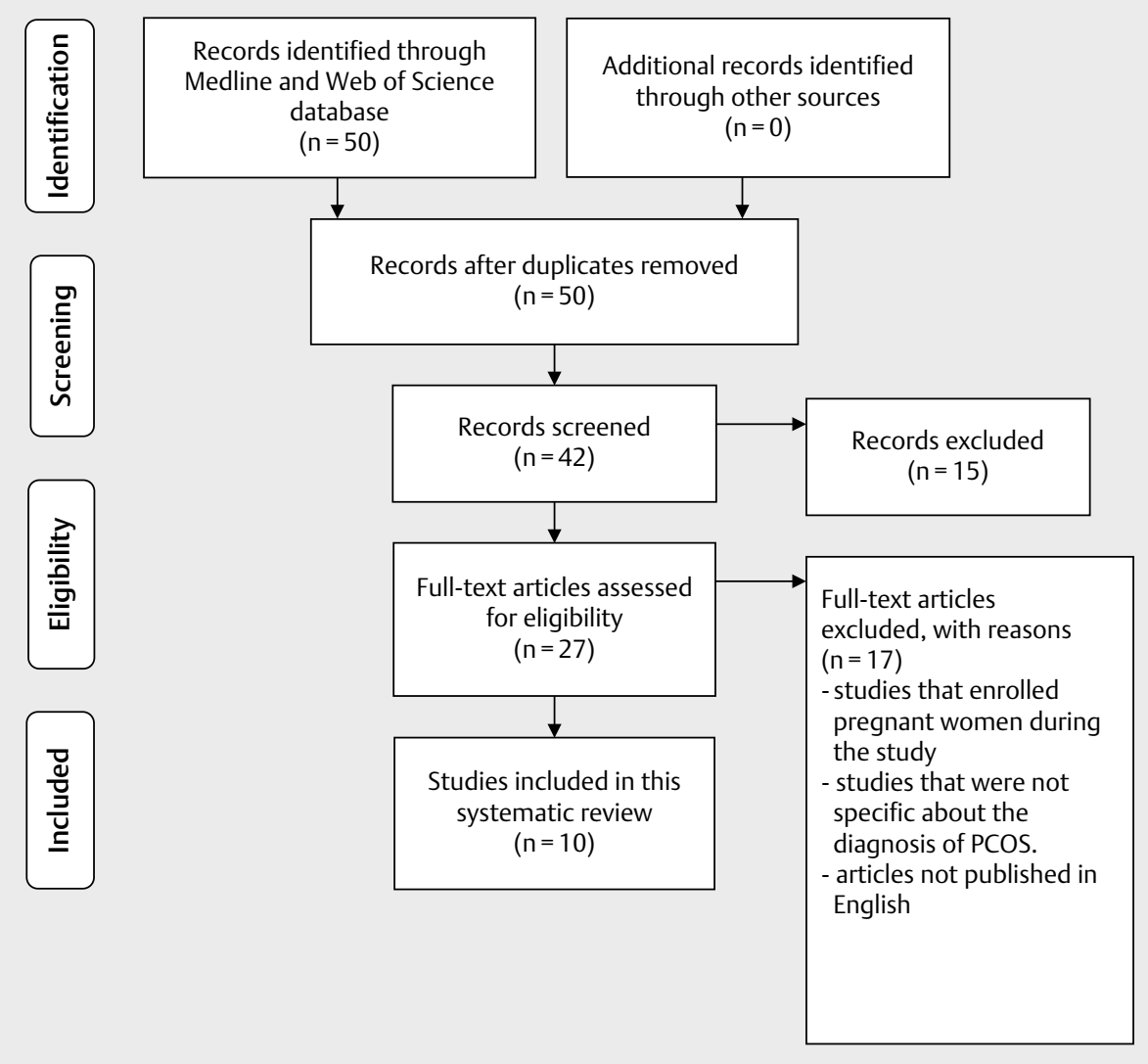

-Fig. 1 Flow chart showing the selection of articles for this systematic review.

The characteristics and results of included studies are presented in

- Tables 1 and 2 .

In all studies reporting metabolic profiles, fasting blood samples were taken at baseline and after the treatment. Serum $25(\mathrm{OH})$ $D$, insulin, serum CRP, and DHEAS were determined by an ELISA kit. Insulin- resistance was considered as HOMA-IR > 2.5. Lastly, serum total testosterone and SHBG with inter and assay coefficient variation (CV) of 3-9\%, was determined by commercial kits. All measurements included in these studies were measured at baseline and after the treatment.

Vitamin D supplementation has shown to significantly increase the level of serum $25(\mathrm{OH}) \mathrm{D}(\mathrm{p}<0.001)$ in patients treated with vitamin $D$ compared with placebo or a low dosage of vitamin $D$ in nine studies [5, 7, 15, 18-21, 23]. The effect of vitamin D supplementation on glycemic status and insulin sensitivity was also reported in all the studies. As shown in > Fig. 1, the main outcomes showed that vitamin $D$ supplementation resulted in beneficial effects on metabolic profiles, including fasting plasma glucose and insulin level, total testosterone, HOMA-IR, hirsutism, and CRP. The seven studies that compared the effect of vitamin D supplementation with placebo, showed significant reductions in the total testosterone $(p<0.001)$, insulin levels $(p=0.007)$, hirsutism $(p<0.001)$, HOMA-IR $(p=0.008)$, and CRP $(p<0.001)[2,5,7$, $18,19,21,23]$. However, vitamin $D$ supplementation was negatively correlated with the quantitative insulin sensitivity check index
(QUICKI) and fasting glucose [20]. One of the studies investigated supplementation of vitamin $D_{3}$ and the effect on metabolic parameters and HOMA- IR showing no significant results throughout the whole intervention of 8 months [11]. Two studies combined the effect of vitamin D supplementation and calcium with placebo, established that those taking calcium plus vitamin D supplements had greater decrease in homeostatic model assessment beta-cell function (HOMA-B) $(p=0.03)$, serum high sensitivity CRP $(p=0.04)$ and plasma MDA concentrations $(p=0.009)$ compared with calcium alone, vitamin $D$ alone and placebo groups [17,22]. The study that compared high dose of vitamin $\mathrm{D}_{3}$ (cholecalciferol) $12000 \mathrm{IU}$ supplementation with placebo for 12 weeks, showed no significant difference in QUICKI, fasting insulin, fasting glucose, and HOMA-IR. However, decreased 2-hour insulin $(p=0.05)$ and lower glucose level was observed with vitamin D supplementation [20]. The vitamin $D$ dose used was significantly higher than the vitamin $D$ guidelines, which could lead to serious adverse effects [20]. A recent study conducted in Austria found that supplementation of vitamin $D$ does not have a significant effect on plasma glucose area under the curve (AUCglu) after 24 weeks, but it significantly reduced the plasma glucose during oral glucose tolerance test [21]. This suggests that vitamin $D$ had no significant effects on metabolic or endocrine parameters [21].

Metformin can cause a significant improvement in weight, insulin level, body mass index, insulin resistance, and parathyroid 
- Table 1 Summary of the study characteristics of the randomized controlled trials.

\begin{tabular}{|c|c|c|c|c|}
\hline Subjects & Study Design & $\begin{array}{l}\text { Diagnostic } \\
\text { Criteria }\end{array}$ & Interventions & $\begin{array}{l}\text { Refer- } \\
\text { ence }\end{array}$ \\
\hline $\begin{array}{l}\text { Insulin resistant }(\text { HOMAR-IR }>2.5) \\
\text { Aged 18-40 years }(n=90) \\
\text { Arak, Iran from March } 2016 \text { to } \\
\text { December } 2016\end{array}$ & $\begin{array}{l}\text { Randomized, } \\
\text { double-blind, } \\
\text { placebo-con- } \\
\text { trolled trial }\end{array}$ & $\begin{array}{l}\text { Rotterdam } \\
\text { criteria }\end{array}$ & $\begin{array}{l}\text { Randomly assigned into three groups to take either high dose } \\
\text { vitamin } D+\text { metformin ( } 4000 \mathrm{IU} / \text { day) or low dose vitamin D } \\
\text { + metformin ( } 1000 \mathrm{IU} / \text { day) or vitamin D placebo + metformin } \\
\text { for } 12 \text { weeks }\end{array}$ & [15] \\
\hline $\begin{array}{l}\text { Insulin resistance in the range of } \\
1.4-4\left(\mathrm{BMI}=17-34 \mathrm{~kg} / \mathrm{m}^{2}\right) \\
\text { Aged } 18-40 \text { years }(\mathrm{n}=60) \text { Iran }\end{array}$ & $\begin{array}{l}\text { Randomized } \\
\text { double-blinded, } \\
\text { placebo-con- } \\
\text { trolled trial }\end{array}$ & $\begin{array}{l}\text { Rotterdam } \\
\text { criteria }\end{array}$ & $\begin{array}{l}\text { Randomized to take } 50000 \mathrm{IU} \text { vitamin D every } 2 \text { weeks plus } \\
8 \times 10^{9} \mathrm{CFU} / \text { probiotic or placebo for } 12 \text { weeks }\end{array}$ & [7] \\
\hline $\begin{array}{l}\text { Infertile women with PCOS } \\
\text { Aged } 18-40 \text { years }(n=40) \text { Iran }\end{array}$ & $\begin{array}{l}\text { Randomized, } \\
\text { double-blinded, } \\
\text { placebo-con- } \\
\text { trolled trial }\end{array}$ & $\begin{array}{l}\text { Rotterdam } \\
\text { criteria }\end{array}$ & $\begin{array}{l}\text { Randomly assigned into two intervention groups to receive } \\
\text { either } 50000 \text { IU vitamin D or placebo every other week for } \\
8 \text { weeks }\end{array}$ & [18] \\
\hline $\begin{array}{l}\text { Overweight vitamin D deficient } \\
\text { women diagnosed with PCOS Aged } \\
18-40 \text { years }(n=104) \text { Iran }\end{array}$ & $\begin{array}{l}\text { Randomized, } \\
\text { double-blinded, } \\
\text { placebo-con- } \\
\text { trolled clinical } \\
\text { trail }\end{array}$ & $\begin{array}{l}\text { Rotterdam } \\
\text { criteria }\end{array}$ & $\begin{array}{l}\text { Randomly divided into four groups. } \\
\text { Group A: } 1000 \mathrm{mg} \text { calcium daily and vitamin D placebo } \\
\text { weekly } \\
\text { Group B: } 50000 \mathrm{IU} \text { vitamin D weekly and calcium placebo } \\
\text { daily } \\
\text { Group C: } 1000 \mathrm{mg} \text { calcium plus } 50000 \mathrm{IU} \text { vitamin D weekly } \\
\text { Group D: calcium placebo daily plus vitamin D placebo weekly } \\
\text { for } 8 \text { weeks }\end{array}$ & [21] \\
\hline $\begin{array}{l}\text { Vitamin D deficient (serum } \\
\text { concentrations < } 20 \mathrm{ng} / \mathrm{ml} \text { ) } \\
\text { Phenotype B (oligo-anovulation } \\
\text { and hyperandrogenism) } \\
\text { Aged } 18-40 \text { years }(\mathrm{n}=70) \\
\text { Kosar Clinic in Iran between April } \\
2016 \text { and June } 2016\end{array}$ & $\begin{array}{l}\text { Randomized } \\
\text { double-blind, } \\
\text { placebo-con- } \\
\text { trolled trial }\end{array}$ & $\begin{array}{l}\text { Rotterdam } \\
\text { criteria }\end{array}$ & $\begin{array}{l}\text { Randomly allocated into } 2 \text { groups to take either } 50000 \mathrm{IU} \\
\text { vitamin D or placebo every } 2 \text { weeks for } 12 \text { weeks }\end{array}$ & [19] \\
\hline $\begin{array}{l}\text { Vitamin D deficient } \\
\text { Aged } 18-45 \text { years }(\mathrm{n}=40) \\
\text { Academic Diabetes, Endocrinology, } \\
\text { and Metabolism Unit, Hull } \\
\text { University Teaching Hospital in } \\
\text { United Kingdom }\end{array}$ & $\begin{array}{l}\text { Randomized, } \\
\text { double-blind, } \\
\text { placebo-con- } \\
\text { trolled trial }\end{array}$ & $\begin{array}{l}\text { Rotterdam } \\
\text { criteria }\end{array}$ & $\begin{array}{l}\text { Randomized to vitamin D ( } 3200 \mathrm{IU}) \text { or placebo daily for } \\
3 \text { months }\end{array}$ & [5] \\
\hline $\begin{array}{l}\text { Referred to obstetrics and } \\
\text { gynecology clinic of Al Zahra } \\
\text { hospital } \\
\text { Aged } 20-40 \text { years ( } n=80 \text { ) Chronic } \\
\text { unovulation, clinical or biochemical } \\
\text { evidence of hyperandrogenism, } \\
\text { and roll out of other causes (thyroid } \\
\text { stimulating hormone, follicle- } \\
\text { stimulating hormone, prolactin and } \\
\text { testosterone measurement) }\end{array}$ & $\begin{array}{l}\text { Randomized, } \\
\text { double-blinded, } \\
\text { placebo } \\
\text { controlled trial }\end{array}$ & NIH criteria & $\begin{array}{l}\text { First group, metformin group; received } 1500 \mathrm{mg} / \text { day } \\
\text { Second, metformin plus calcium and vitamin D; received } \\
1500 \mathrm{mg} / \text { day metformin plus } 1000 \mathrm{mg} / \text { day calcium plus } \\
50000 \mathrm{IU} / 2 \text { weeks of vitamin D. Third, calcium and vitamin D; } \\
\text { received } 1000 \mathrm{mg} / \text { day calcium plus } 50000 \mathrm{IU} / 2 \text { weeks of } \\
\text { vitamin D } \\
\text { Last, placebo group; received two low calorie sweetener } \\
\text { tablets per day. }\end{array}$ & [17] \\
\hline $\begin{array}{l}\text { Aged } 18-45 \text { years }(n=22) \\
\text { Recruited through Medicine and } \\
\text { Obstetrics and Gynecology clinics } \\
\text { at Penn State }\end{array}$ & $\begin{array}{l}\text { Randomized, } \\
\text { double-blind, } \\
\text { placebo } \\
\text { controlled trial }\end{array}$ & NIH criteria & $\begin{array}{l}\text { Randomized to take either vitamin } D_{3} \text { (cholecalciferol) } \\
12000 \text { IU or placebo daily for } 12 \text { weeks }\end{array}$ & [20] \\
\hline $\begin{array}{l}\text { Vitamin D deficient } \\
\text { Aged } 18-45 \text { years }(n=86) \\
\text { Clinics of endocrine disease at } \\
\text { Golestan and Inam Khomeini } \\
\text { Hospitals of Ahvaz, Iran }\end{array}$ & $\begin{array}{l}\text { Randomized- } \\
\text { blinded clinical } \\
\text { trial }\end{array}$ & $\begin{array}{l}\text { Rotterdam } \\
\text { criteria }\end{array}$ & $\begin{array}{l}\text { The patients were randomized into two groups depending } \\
\text { upon their vitamin D and BMI. One group of } 42 \text { patients } \\
\text { received a vitamin D dose of } 50000 \mathrm{IU} \text { monthly. The other } \\
\text { group of } 44 \text { patients received a vitamin D dose of } 50000 \mathrm{IU} \\
\text { weekly. The patient's markers were tested after } 8 \text { months of } \\
\text { treatment }\end{array}$ & [11] \\
\hline $\begin{array}{l}\text { Premenopausal women with PCOS } \\
\text { and } 25 \text { - hydroxyvitamin } D \\
\text { concentrations }<75 \mathrm{nmol} / \mathrm{l} \\
\text { Aged }>18 \text { years }(\mathrm{n}=123 \text { ) } \\
\text { Medical University of Graz, Austria }\end{array}$ & $\begin{array}{l}\text { Single- center, } \\
\text { double-blind, } \\
\text { randomized } \\
\text { placebo-con- } \\
\text { trolled trial }\end{array}$ & $\begin{array}{l}\text { Rotterdam } \\
\text { criteria }\end{array}$ & $\begin{array}{l}\text { Subjects were randomized in a 2:1 ratio to either receive } \\
20000 \mathrm{IU} \text { of cholecalciferol weekly or placebo over } 24 \text { weeks }\end{array}$ & [23] \\
\hline
\end{tabular}


- Table 2 Summary of findings from the randomized controlled trials.

\begin{tabular}{|c|c|}
\hline Reference & Results \\
\hline [15] & $\begin{array}{l}\text { Significant increase in } 25(\mathrm{OH}) \text { D values }(p<0.001) \text { compared with low dose and placebo group. } \\
\text { Significant reductions in FPG }(p=0.009) \text {, serum insulin levels }(p=0.003) \text {, HOMA-IR }(p=0.004) \text {, total testosterone }(p=0.02) \text {, } \\
\text { hirsutism }(p=0.001) \text { and CRP }(p=0.01) \text { compared to low dose and placebo group. } \\
\text { Significant elevations in mean change of SHBG }(p<0.001) \text { and TAC }(p<0.001) \text { in high dose group compared with low- dose and } \\
\text { placebo group. }\end{array}$ \\
\hline [7] & $\begin{array}{l}\text { Vitamin } D \text { and probiotic improved beck depression inventory }(p=0.04) \text {, general health questionnaire }(p=0.03) \text { and depression } \\
\text { anxiety and stress scale }(p=0.02) \text { compared with placebo. } \\
\text { Significant reduction in total testosterone }(p<0.001) \text {, hirsutism }(p<0.001) \text {, CRP }(p<0.001) \text { and MDA levels }(p=0.001) \text { compared to } \\
\text { placebo. } \\
\text { Significant increase in TAC }(p<0.001) \text { and GSH levels }(p=0.02) \text {. }\end{array}$ \\
\hline [18] & $\begin{array}{l}\text { Vitamin D supplementation led to a significant reduction in serum anti-Müllerian hormone }(p=0.02) \text {, insulin levels }(p=0.007) \text {, } \\
\text { HOMA-IR }(p=0.008) \text { compared to placebo. } \\
\text { Significantly decreased serum total }(p=0.03) \text { and LDL cholesterol levels }(p=0.04)\end{array}$ \\
\hline [21] & $\begin{array}{l}\text { Those taking calcium plus vitamin } D \text { supplements had greater decreases in HOMA-B }(p=0.03) \text {, serum high sensitivity CRP }(p=0.04) \\
\text { and plasma MDA concentrations }(p=0.009) \text {. } \\
\text { Significant increases in plasma TAC }(p=0.006) \text { and GSH levels }(p=0.001) \text { compared with calcium alone, vitamin D alone and placebo } \\
\text { groups. }\end{array}$ \\
\hline [19] & $\begin{array}{l}\text { Compared to placebo, vitamin D supplementation significantly decreased FPG }(p=0.02) \text {, insulin }(0.004) \text {, HOMA-B }(p=0.005) \text {, and } \\
\text { increased quantitative insulin sensitivity check index }(p=0.007) \text {. } \\
\text { Significant reductions in serum CRP }(p=0.009) \text {, and MDA levels }(p=0.01) \text {. }\end{array}$ \\
\hline [5] & $\begin{array}{l}\text { Greater increases in vitamin D levels were shown in the supplementation group }(p<0.001) \text {. } \\
\text { Between group comparisons revealed significant differences in ALT }(p=0.0042) \text {, and a weak effect indicating a greater reduction in } \\
\text { HOMA-IR in the vitamin D group }(p=0.051) \text {. }\end{array}$ \\
\hline [17] & $\begin{array}{l}\text { Regular menstrual cycle and dominant follicle after intervention in both group was significantly increased }(p=0.001) \\
\text { Hirsutism significantly improved after the intervention in only the second group }(p=0.001) \text {. }\end{array}$ \\
\hline [20] & $\begin{array}{l}\text { Within the vitamin D group, there was a significant increase in serum } 25(\mathrm{OH}) \mathrm{D} \text { from baseline to } 12 \text { weeks }(\mathrm{p}<0.001) \text {. } \\
\text { Changes in QUICKI, other measures of glucose and insulin metabolism, HOMA-IR, and a reduction in the } 2 \mathrm{~h} \text { insulin level at } 12 \text { weeks } \\
(\mathrm{p}=0.005) \text {. }\end{array}$ \\
\hline [11] & $\begin{array}{l}\text { Significant difference in the level of FBS before and after the treatment }(p<0.05) \text {. } \\
\text { No significant difference in the metabolic parameters and HOMA-IR. }\end{array}$ \\
\hline [23] & $\begin{array}{l}\text { Vitamin D supplementation led to a significant increase in } 25(\mathrm{OH}) \mathrm{D}(\mathrm{p}<0.001) \text { but had no significant effect on AUCgluc }(p=0.139) \text {. } \\
\text { Regarding secondary outcome measures, a significant decrease in plasma glucose at } 60 \text { min during oral glucose tolerance test }(p= \\
0.045) \text { was observed. }\end{array}$ \\
\hline
\end{tabular}

hormone. However, since metformin was coupled with the two dosages, metformin did not have any side effects with the amount given to the groups, or significant effect in HOMA-IR (or other parameters of $\mathrm{PCOS}$ ) was observed after 12 weeks of metformin treatment in the placebo and the low dose vitamin D group. This may be due to lack of efficacy of metformin in the cohort [15].

Seven out of the ten studies that were included in this systematic review were controlled trials held in the country of Iran. It must be considered that in many of these studies, baseline levels of vitamin D among insulin-resistant patients with PCOS are low. However, vitamin D deficiency is highly prevalent in Iranian women due to their particular form of dressing and coverage. Earlier studies in Iran have shown that PCOS is prevalent among $20 \%$ of adult women and vitamin D deficiency affects $75 \%$ of women. The other three studies were conducted in the United States, United Kingdom, and Austria, respectively.

\section{Discussion}

We conducted a systematic review of the randomized controlled trials to determine the efficacy of vitamin D supplementation on the metabolic and hormonal profiles in women with PCOS. Moreover, it seems from the literature that women with PCOS and vitamin D deficiency respond less favorably to glucose metabolism. Evidence suggests that vitamin D supplementation can increase serum 25(OH) D levels of patients with PCOS. We found that the use of vitamin D supplementation for PCOS patients may improve insulin resistance and other metabolic profiles, especially when combined with calcium.

Vitamin D deficiency is common in women with and without PCOS, with $10-60 \%$ of adults having serum levels lower than $20 \mathrm{ng} /$ $\mathrm{ml}[2,10]$. Accumulating evidence indicates that serum vitamin $\mathrm{D}$ may play important roles, such as in enhancing insulin synthesis and release, and increasing insulin receptor expression or suppression of proinflammatory cytokines that possibly contribute to the development of insulin resistance [15]. The metabolic syndrome is characterized as a chronic state of low-grade inflammation with increased levels of tumor necrosis factor $\alpha$ (TNF- $\alpha$ ) and interleukin 6 
(IL-6) [24]. This might be due to the alteration of the tissue inhibitor of metalloproteases 3-TNF- $\alpha$ converting enzyme (TIMP3-TACE) dyad in skeletal muscle [25-27]. Insulin resistance increases hyperandrogenism through insulin increasing ovarian androgen production and reducing SHBG production. Metabolically, insulin resistance is associated with an increased risk for impaired glucose tolerance, type 2 diabetes mellitus, and cardiovascular disease [1]. Therefore, vitamin D plays a vital role in the development of PCOS. From many of the studies observed, we obtained the consistent results that vitamin D supplementation did influence insulin metabolism, but did not affect glucose parameters in PCOS patients, despite a significant increase in serum $25(\mathrm{OH}) \mathrm{D}$. However, many of the studies in this review included participants who were overweight and obese. Rashidi et al. suggest that there were no significant associations between 25(OH) D and metabolic parameters in non-obese women with PCOS [11]. Metformin can reduce the hyper androgenic signs and symptoms of PCOS patients by reducing the levels of androgen [17]. In a clinical trial, combination of metformin, vitamin D and calcium showed significant improvement on the menstural regularity and hyperandrogenic symptoms of PCOS patients compared to treatment with metformin alone [17]. Also, as vitamin $\mathrm{D}$ deficiency is highly prevalent among women at reproductive age, the role of only vitamin $D$ supplementation in fertility treatment was not discussed in many of these articles. There is not enough evidence indicating whether or not the treatment with vitamin D supplementation causes any significant changes in the menstrual cycles or dominant follicles.

The strengths of this review included specified inclusion and exclusion criteria of studies, the comprehensive literature search, articles that were relatively new, and the different parameters each study measured. However, this review had some limitations. First, many of the studies enrolled a small number of participants and had short duration of treatment and follow-up. Second, most of the studies were done in Iran, which is a country that has unique cultural features. In this case, we do not know what allowed many of the subjects to be vitamin D deficient. Despite the limitations of the review, there appears to be sufficient evidence that there are some beneficial effects of vitamin D supplementation on the metabolic profiles of women with PCOS.

\section{Conclusions}

The current systematic review shows that vitamin $D$ supplementation can improve some of the metabolic parameters in patients with PCOS, although there is not sufficient evidence that glucose metabolism is affected. Further studies should focus on the benefits of vitamin D supplementation on hormonal, metabolic profiles, and female reproduction in obese and non-obese women with PCOS. Also, there needs to be future studies on the role of vitamin D and its receptors on these different parameters in the body. Due to limited evidence, adding high quality randomized, double-blinded, placebo-controlled trials with large sample sizes, longer treatment durations, and follow up that evaluates the female reproduction, hormonal, and metabolic profiles is necessary. Future research on this topic may provide robust evidence about vitamin D supplementation and its use as therapy towards improving insulin sensitivity that could lower the risk of PCOS.

\section{Conflict of Interest}

The authors declare that they have no conflict of interest.

\section{References}

[1] Fica S, Albu A, Constantin M et al. Insulin resistance and fertility in polycystic ovary syndrome. J Med Life 2008; 1: 415-422

[2] Rashidi H, Toolabi M, Najafian M et al. The relationship of serum 25-dihydroxy vitamin D3 concentrations with metabolic parameters in non-obese women with polycystic ovarian syndrome. Middle East Fertil Soc J 2016; 21: 264-268

[3] Patra SK, Nasrat H, Goswami B et al. Vitamin D as a predictor of insulin resistance in polycystic ovarian syndrome. Diabetes Metab Syndr 2012; 6: 146-149

[4] He C, Lin Z, Robb SW et al. Serum vitamin D levels and polycystic ovary syndrome: A systematic review and meta-analysis. Nutrients 2015; 7: 4555-4577

[5] Javed Z, Papageorgiou M, Deshmukh H et al. A Randomized, controlled trial of vitamin $\mathrm{D}$ supplementation on cardiovascular risk factors, hormones, and liver markers in women with polycystic ovary syndrome. Nutrients 2019; 11: 188

[6] Fang F, Ni K, Cai Y et al. Effect of vitamin D supplementation on polycystic ovary syndrome: A systematic review and meta-analysis of randomized controlled trials. Complement Ther Clin Pract 2017; 26: 53-60

[7] Ostadmohammadi V, Jamilian M, Bahmani F et al. Vitamin D and probiotic co-supplementation affects mental health, hormonal, inflammatory and oxidative stress parameters in women with polycystic ovary syndrome. J Ovarian Res 2019; $12: 5$

[8] Thomson RL, Spedding S, Buckley JD. Vitamin D in the aetiology and management of polycystic ovary syndrome. Clin Endocrinol (Oxf) 2012; 77: 343-350

[9] Demer LL, Hsu J], Tintut Y. Steroid Hormone Vitamin D: Implications for cardiovascular disease. Circ Res 2018; 122: 1576-1585

[10] Hilger J, Friedel A, Herr R et al. A systematic review of vitamin D status in populations worldwide. Br J Nutr 2014; 111: 23-45

[11] Rashidi H, Ghaderian SB, Moradi L. The effect of vitamin D3 on improving lipid profile, fasting glucose and insulin resistance in polycystic ovary syndrome women with vitamin D deficiency. Middle East Fertil Soc J 2018; 23: 178-183

[12] Lagunova Z, Porojnicu AC, Lindberg F et al. The dependency of vitamin $D$ status on body mass index, gender, age and season. Anticancer Res 2009; 29: 3713-3720

[13] Parikh SJ, Edelman M, Uwaifo Gl et al. The relationship between obesity and serum 1,25-dihydroxy vitamin $\mathrm{D}$ concentrations in healthy adults. J Clin Endocrinol Metab 2004; 89: 1196-1199

[14] Xue Y, Xu P, Xue K et al. Effect of vitamin D on biochemical parameters in polycystic ovary syndrome women: A meta-analysis. Arch Gynecol Obstet 2017; 295: 487-496

[15] Jamilian M, Foroozanfard F, Rahmani E et al. Effect of two different doses of vitamin $D$ supplementation on metabolic profiles of insulin-resistant patients with polycystic ovary syndrome. Nutrients 2017; 9: 1280

[16] Pal L, Berry A, Coraluzzi L et al. Therapeutic implications of vitamin D and calcium in overweight women with polycystic ovary syndrome. Gynecol Endocrinol 2012; 28: 965-968

[17] Tehrani HG, Mostajeran F, Shahsavari S. The effect of calcium and vitamin $\mathrm{D}$ supplementation on menstrual cycle, body mass index and hyperandrogenism state of women with poly cystic ovarian syndrome. J Res Med Sci 2014; 19: 875-880 
[18] Dastorani M, Aghadavod E, Mirhosseini N et al. The effects of vitamin D supplementation on metabolic profiles and gene expression of insulin and lipid metabolism in infertile polycystic ovary syndrome candidates for in vitro fertilization. Reprod Biol Endocrinol 2018; 16: 94

[19] Maktabi M, Chamani M, Asemi Z. The effects of vitamin D supplementation on metabolic status of patients with polycystic ovary syndrome: A randomized, double-blind, placebo-controlled trial. Horm Metab Res 2017; 49: 493-498

[20] Raja-Khan N, Shah J, Stetter CM et al. High-dose vitamin D supplementation and measures of insulin sensitivity in polycystic ovary syndrome: A randomized, controlled pilot trial. Fertil Steril 2014; 101: 1740-1746

[21] Trummer C, Schwetz V, Kollmann M et al. Effects of vitamin D supplementation on metabolic and endocrine parameters in PCOS: A randomized controlled trial. Eur J Nutr 2019; 58: 2019-2028

[22] Foroozanfard F, Jamilian M, Bahmani F et al. Calcium plus vitamin D supplementation influences biomarkers of inflammation and oxidative stress in overweight and vitamin D-deficient women with polycystic ovary syndrome: A randomized double-blind placebo-controlled clinical trial. Clin Endocrinol (Oxf) 2015; 83: 888-894
[23] Wehr E, Pieber TR, Obermayer-Pietsch B. Effect of vitamin D3 treatment on glucose metabolism and menstrual frequency in polycystic ovary syndrome women: a pilot study. J Endocrinol Invest 2011; 34: 757-763

[24] Kern PA, Ranganathan S, Li C et al. Adipose tissue tumor necrosis factor and interleukin-6 expression in human obesity and insulin resistance. Am J Physiol Endocrinol Metab 2001; 280: E745-E751

[25] Federici M, Hribal ML, Menghini R et al. Timp3 deficiency in insulin receptor-haploinsufficient mice promotes diabetes and vascular inflammation via increased TNF-alpha. J Clin Invest 2005; 115: 3494-3505

[26] Monroy A, Kamath S, Chavez AO et al. Impaired regulation of the TNF-alpha converting enzyme/tissue inhibitor of metalloproteinase 3 proteolytic system in skeletal muscle of obese type 2 diabetic patients: A new mechanism of insulin resistance in humans. Diabetologia 2009; 52: $2169-2181$

[27] Tripathy D, Daniele G, Fiorentino TV et al. Pioglitazone improves glucose metabolism and modulates skeletal muscle TIMP-3-TACE dyad in type 2 diabetes mellitus: a randomised, double-blind, placebo-controlled, mechanistic study. Diabetologia 2013; 56: 2153-2163 